SHORT REPORT

\title{
Functional dimorphism of two hAgRP promoter SNPs in linkage disequilibrium
}

\author{
F Bai, T Rankinen, C Charbonneau, D D Belsham, D C Rao, C Bouchard, G Argyropoulos
}

J Med Genet 2004;41:350-353. doi: 10.1136/jmg.2003.014092

The agouti related protein (AgRP) exerts its anabolic effects on food intake by antagonising the alpha-melanocyte stimulating hormone $(\alpha-M S H)$ at its receptors, melanocortin receptors 3 and 4 (MC3R and MC4R). A single nucleotide polymorphism (SNP) in the promoter of the human AgRP (hAgRP), $-38 \mathrm{C}>\mathrm{T}$, was associated with low body fatness. The $-38 T$ allele that was associated with low body fatness also resulted in lower promoter activity. Here we report a novel SNP, $-3019 \mathrm{G}>\mathrm{A}$, again in the promoter of hAgRP, which is in complete linkage disequilibrium (LD) with the $-38 \mathrm{C}>\mathrm{T}$ SNP (linked alleles: $-3019 \mathrm{~A} /-38 \mathrm{~T}$ and $-3019 \mathrm{G} /-38 \mathrm{C}$. Functional analyses in a human adrenal and two mouse hypothalamus cell lines showed that the -3019 A allele had significantly higher promoter activity. Hence, the two linked alleles $(-3019 A$ and $-38 T)$ had opposite effects on promoter function and yet they were both associated with low body fatness. The region encompassing the $-38 \mathrm{C}>\mathrm{T}$ SNP had approximately 1000-fold higher activity than the region encompassing the $-3019 \mathrm{G}>\mathrm{A}$ SNP, potentially determining the net functional effect between these two SNPs.

$\mathrm{T}$ he agouti related protein (AgRP) is expressed in the arcuate nucleus of the hypothalamus, the testes, the lung, and the adrenal gland, and is upregulated in obese and diabetic mice. ${ }^{1-3}$ AgRP exerts its anabolic effects on food intake by antagonising the alpha-melanocyte stimulating hormone $(\alpha-\mathrm{MSH})$ at its receptors, melanocortin receptors 3 and 4 (MC3R and MC4R). ${ }^{45}$ When administered intracerebroventricularly (i.c.v. ${ }^{6}$ or when overexpressed in transgenic mice, ${ }^{7}$ both the murine and human AgRP orthologs stimulate hyperphagia. Streptozotocin-induced diabetes resulted in upregulation of $\mathrm{AgRP},{ }^{8}$ while chronic i.c.v. administration of AgRP resulted in a decrease in expression of the uncoupling protein 1 (UCP1) in the rat,, suggesting a role for AgRP in energy expenditure. AgRP also has an inhibitory paracrine role in the rat adrenal gland by blocking $\alpha$-MSH-induced corticosterone secretion. ${ }^{10}$ Leptin downregulates AgRP expression, ${ }^{11}$ while human AgRP (hAgRP) can itself be a negative regulator of leptin action. ${ }^{12}$ AgRP, therefore, plays a significant role in the regulation of food intake.

Elevated plasma levels of hAgRP have been reported in obese men, ${ }^{13}$ suggesting its involvement in the development of human obesity. Moreover, a 2 -h fast resulted in a $73 \%$ increase of plasma hAgRP concentration, which is consistent with studies reported in animals. ${ }^{14}$ An SNP in the coding region of the gene (Ala67Thr) was associated with anorexia nervosa, ${ }^{15}$ implicating hAgRP in the development of eating disorders, while the same SNP was associated with the prevention of late-onset obesity in white subjects. ${ }^{16}$ An SNP in the promoter of $\mathrm{AgRP},-38 \mathrm{C}>\mathrm{T}$, was significantly associated with low BMI in Sierra Leoneans ${ }^{17}$ and had a significant protective role against body fatness in blacks of the diaspora (African Americans and African Canadians). ${ }^{18}$ The $-38 \mathrm{C}>\mathrm{T}$ SNP is positioned in the minimal promoter region of AgRP that has been shown to have high promoter activity in hypothalamus-and periphery-derived cell lines. ${ }^{17} 19$

In the present study we report a novel SNP, $-3019 \mathrm{G}>\mathrm{A}$, identified in the distal promoter of AgRP and in a region that has significantly lower activity than the proximal promoter region. ${ }^{20}$ The $-3019 \mathrm{G}>\mathrm{A}$ SNP was in complete linkage disequilibrium (LD) with the $-38 \mathrm{C}>\mathrm{T}$ SNP, but the linked genotypes of the two SNPs exerted opposite effects on promoter activity (as assessed by in vitro cell culture models).

\section{METHODS \\ Subjects}

The HERITAGE Family Study cohort included 259 black subjects ( 88 men and 171 women) from 114 family units. The study design and inclusion criteria have been previously described. ${ }^{21}$ Although the HERITAGE cohort includes both Caucasian and black subjects, the $-38 \mathrm{C}>\mathrm{T}$ SNP was found in the blacks subjects only. Therefore no Caucasian data were used in the statistical analyses. The study protocols were approved by each of the Institutional Review Boards of the HERITAGE Family Study research consortium. Written informed consent was obtained from each participant.

\section{Genotyping}

Initial screening for polymorphisms in the promoter region of AgRP was carried out using a representative cohort of 40 individuals consisting of diabetic, obese, and lean white and black subjects. Several combinations of primers were used for amplification of genomic DNA by polymerase chain reaction (PCR) and bidirectional sequencing of the amplicons on an ABI 3700 DNA Analyzer (Applied Biosystems, Foster City, $\mathrm{CA})$. Once the $-3019 \mathrm{G}>\mathrm{A}$ SNP was identified, genotyping was performed by amplification of genomic DNA and direct sequencing using a probe on the LI-COR DNA Analyzer 4200 (Lincoln, NE). The following primers were used: forward primer: 5' -ATT TAA CGC GTC CAT CTT CTC CTC TCC CTG-3'; reverse primer: 5'-CTT GGG CTA GTC AGC TGA GAT CGT GCC ACT G-3'; LI-COR probe: 5'-CCT GGA CAA GGT GGG AAC AG-3'. PCR was performed as previously described. ${ }^{17}$ Since its identification in our laboratory, SNP $-3019 \mathrm{G}>\mathrm{A}$ has appeared in dbSNP with the rs \#: 8047574. The nomenclature adopted for referencing gene names, symbols, and polymorphism descriptions was according to den Dunnen and Antonarakis. $^{22}$

Abbreviations: AgRP, agouti related protein; $\alpha-M S H$, alphamelanocyte stimulating hormone; LD, linkage disequilibrium; MC3R and MC4R, melanocortin receptors 3 and 4; SNP, single nucleotide polymorphism; UCPI, uncoupling protein 1 


\section{Transfection constructs and cell culture}

Constructs to examine the impact of the $-3019 \mathrm{G}>\mathrm{A}$ SNP on promoter activity were made by amplification of genomic DNA from a heterozygous individual and directional cloning of the PCR products into the pGL3-basic vector (Promega, Madison, WI). The amplified region containing the SNP was 203 nucleotides (nt) long $(-3165 /-2962)$. The forward and reverse primers contained recognition sites for the MluI and NheI restriction endonucleases for digestion of the PCR products to facilitate directional cloning into the vector. The sequence of the primers (inclusive of the restriction sites for the enzymes) was as follows: forward primer: 5'-TTT GAA CGC GTC ACA GGA AAC ACA TGG CTGT-3'; reverse primer: 5'-CTT GGG CTA GCG CTC AAA CCC TCT CCC TTCT-3'. Constructs to examine promoter activity for the $-38 \mathrm{C}>\mathrm{T}$ SNP were prepared as previously described. ${ }^{17}$ Cell culture was carried out under standard conditions in a humidified incubator at $37^{\circ} \mathrm{C}$ and $5 \% \mathrm{CO}_{2}$. The GTl-7 cells were the kind gift of Dr Mellon ${ }^{23}$ and were grown in DMEM medium (Cellgro, cat. no 10-017-cv), 10\% FBS, penicillin-streptomycin (Gibco, cat. no 15140-122) to 1\%. The human adrenal NCI-h295R cells were purchased from the American Type

A

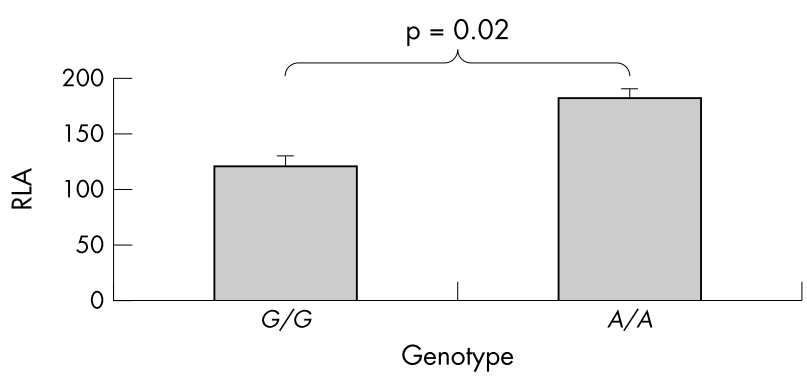

B

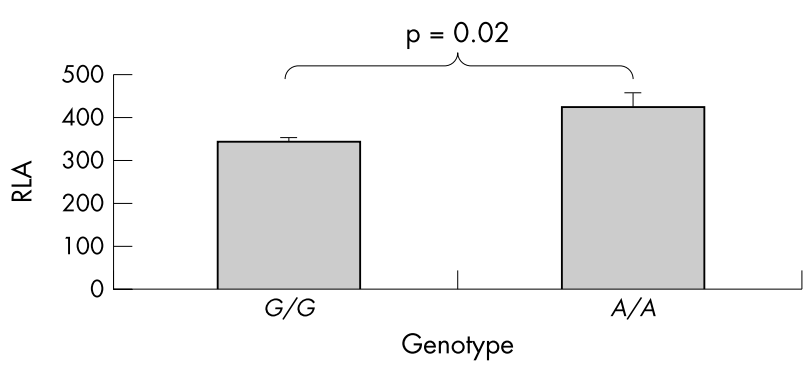

C

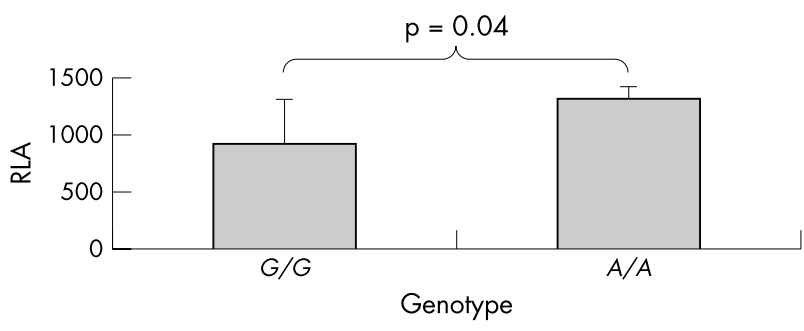

Figure 1 Mean relative luciferase activities for the two genotypes of the -3019G >A SNP, in three cell lines: GT1-7 (A), NCl-h295R (B), and $\mathrm{N}-38$ (C). Luciferase activities were normalised by $\beta$-galactosidase measurements for transfection efficiencies and the values shown are the means of a minimum of nine independent experiments for each genotype in each cell line. The standard deviations are represented by the vertical bars on the columns. Comparisons between genotypes in each cell line were performed by Student's $t$-test and the $p$-values are shown above the bars.
Table 1 Genotype frequencies for the $-3019 \mathrm{G}>\mathrm{A}$ AgRP SNP, allele frequencies for SNPs $-3019 \mathrm{G}>\mathrm{A}$ and $-38 \mathrm{C}>\mathrm{T}$, and linkage disequilibrium test for the two SNPs

\begin{tabular}{llll}
\hline Genotype frequencies & $\boldsymbol{A A}$ & $\mathrm{GA}$ & $\mathrm{GG}$ \\
\hline (-3019G $>\mathrm{A})$ & $16(6.6 \%)$ & $106(43.4 \%)$ & $122(50 \%)$ \\
\hline Locus/allele & $\mathbf{1}$ & $\mathbf{2}$ & \\
\hline$-3019 \mathrm{G}>\mathrm{A}$ & $0.2828(\mathrm{~A})$ & $0.7172(\mathrm{G})$ & \\
$-38 \mathrm{C}>\mathrm{T}$ & $0.7172(\mathrm{C})$ & $0.2828(\mathrm{~T})$ & \\
\hline
\end{tabular}

Linkage disequilibrium test: $\chi^{2}=434.33, p<0.0000001, D^{\prime}=1.0$.

Tissue Collection (Manassas, VA) and were grown in the following media: DMEM/F12 50/50 MIX medium $500 \mathrm{ml}$ (Cellgro, cat. no $15-090-\mathrm{cV}$ ) by adding BD ITS+culture supplement $5 \mathrm{ml}$ (BD Biosciences, cat. no 354352) and Nuserum I culture supplement $13 \mathrm{ml}$ (BD Biosciences, cat. no 35-5100) and 0.75 M HEPES $10.5 \mathrm{ml}$ penicillin-streptomycin (GIBCO, cat. no $15140-122$ ) to $1 \%$. The N-38 is a newly developed cell line that was generated through immortalisation of mouse primary hypothalamic cells at embryonic day 17 with SV40 T-antigen introduced through retroviral infection. The N-38 cell line, a clonal population of hypothalamic neurons, has been propagated to P-44 and maintains SV40 T-antigen expression after 2 years of continuous growth. ${ }^{24}$ Cell culture conditions for the N-38 cells were identical to those for the GT1-7 cells given above.

All cells were serum starved for $24 \mathrm{~h}$ prior to transfection. Transient cotransfections with the AgRP promoter constructs and $\beta$-gal plasmids were carried out for $24 \mathrm{~h}$ in the absence of serum using the Geneporter2 transfection reagent as prescribed by the manufacturer (Gene Therapy Systems, San Diego, CA). Subsequently, the media were supplemented with $20 \%$ FCS for $24 \mathrm{~h}$. Cells were harvested using $\mathrm{l} \times$ Geneporter2 lysis buffer and the lysates were assayed for luciferase and $\beta$-galactosidase activities, as prescribed by the assay manufacturer (Promega, Madison, WI) in a luminometer (Zylux, Pforzheim, Germany). All luciferase activity measurements were normalised to $\beta$-galactosidase values. Measurements were averaged from a series of a minimum of nine independent experiments per cell line.

\section{Statistical analyses}

AgRP $-38 \mathrm{C}>\mathrm{T}$ and $-3019 \mathrm{G}>\mathrm{A}$ haplotype frequencies were assessed using the $\mathrm{EH}$ program..$^{25}$ Linkage disequilibrium (LD) was calculated as $\mathrm{D}^{\prime}=\mathrm{x}_{\mathrm{ij}}-\mathrm{p}_{\mathrm{i}} \mathrm{p}_{\mathrm{j}}$, where $\mathrm{x}_{\mathrm{ij}}$ is the $\mathrm{A}_{1} \mathrm{~B}_{1}$ haplotype frequency, and $\mathrm{p}_{1}$ and $\mathrm{p}_{2}$ are the frequencies of alleles $A_{1}$ and $B_{1}$ at loci $A$ and $B$, respectively. A standardised LD coefficient $\mathrm{D}^{\prime}$ was defined as $\mathrm{D}^{\prime}=\mathrm{D} / \mathrm{D}_{\max }$, where $\mathrm{D}_{\max }=\min \left(\mathrm{p}_{1} \mathrm{p}_{2}, \mathrm{q}_{1} \mathrm{q}_{2}\right)$, when $\mathrm{D}<0$, or $\mathrm{D}_{\max }=$ $\min \left(\mathrm{q}_{1} \mathrm{p}_{2}, \mathrm{p}_{1} \mathrm{q}_{2}\right)$, when $\mathrm{D}>0$, and $\mathrm{q}_{1}$ and $\mathrm{q}_{2}$ are the frequencies of alleles $\mathrm{A}_{2}$ and $\mathrm{B}_{2}$ at loci $\mathrm{A}$ and $\mathrm{B}$, respectively. ${ }^{26}$

\section{RESULTS AND DISCUSSION}

An SNP was identified at position -3019 upstream of the putative transcription start site of the promoter of hAgRP $(-3019 \mathrm{G}>\mathrm{A})$. The functional impact of the SNP was assessed by examining the promoter activity of the region $(-3165 /$ -2962 ) containing the SNP. Two constructs were made in the pGL3-basic luciferase reporter vector representing the two genotypes. The $A / A$ construct had significantly higher promoter activity than the $G / G$ construct in the mouse hypothalamus GT1-7 and the human adrenal NCI-h295R cell lines (fig $1 \mathrm{~A}, \mathrm{~B}$ ). This result was repeated in another mouse hypothalamus neuronal cell line, N-38 (fig IC). The three cell lines endogenously express AgRP as assessed by real-time quantitative RT-PCR (data not shown). 


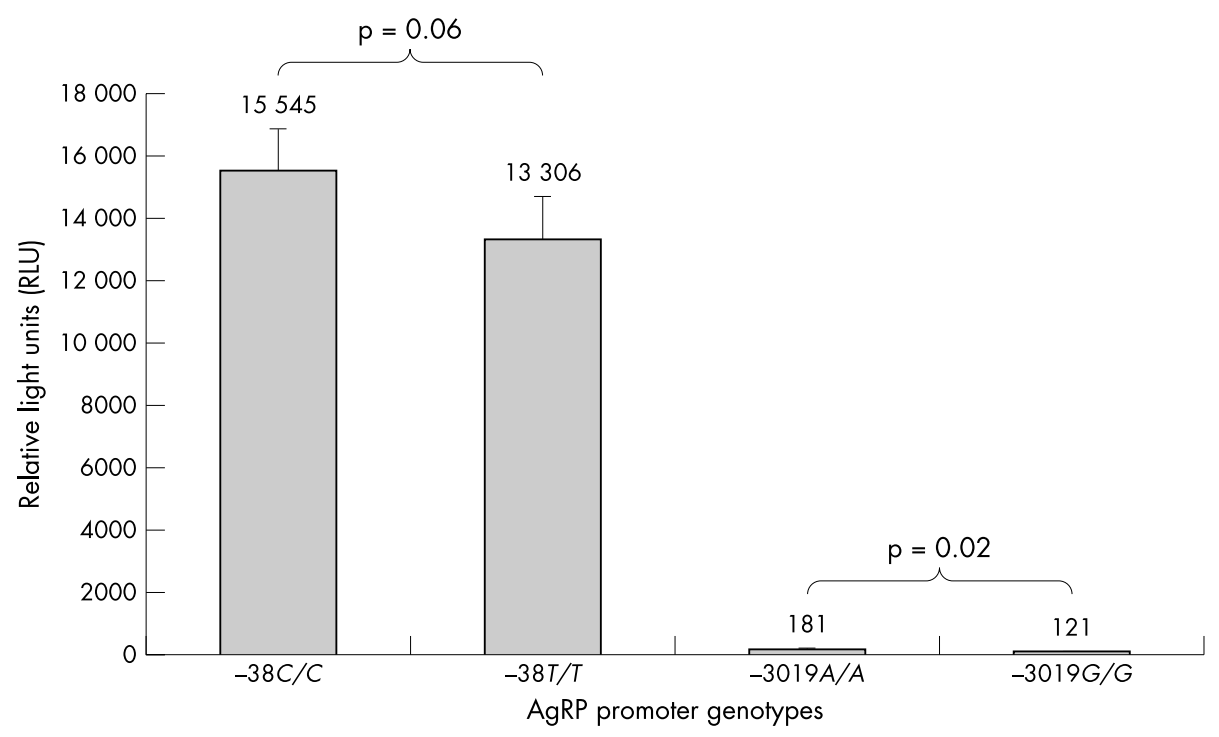

Figure 2 Mean luciferase activities for the genotypes representing the two SNPs $-38 \mathrm{C}>\mathrm{T}$ and $-3019 \mathrm{G}>\mathrm{A}$. The values shown are the actual relative light units (above bars) that were measured by a luminometer. A minimum of eight independent experiments per genotype were performed. The standard deviations are represented by the vertical bars on the columns. Luciferase activities were normalised by $\beta$-galactosidase measurements. Comparisons between genotypes were performed by Student's $t$-test.

The promoter activities of the two $-3019 \mathrm{G}>\mathrm{A}$ constructs were considerably lower than the promoter activities we have measured for other regions of the hAgRP promoter. ${ }^{19}$ Moreover, studies in our laboratory have shown that SNP $-3019 \mathrm{G}>\mathrm{A}$ lies in a region that might have suppressor effects on gene expression..$^{20}$

We subsequently genotyped the HERITAGE Family study population to evaluate the possible association of the -3019G $>$ A SNP with obesity-related phenotypes. The SNP was found in black subjects only which was also the case for the $-38 \mathrm{C}>\mathrm{T}$ SNP. Subsequently we compared the allele frequencies of the two SNPs and found them to be identical between the " $A-T$ " and the " $G-C$ " pairs (table 1). This pattern indicates strong linkage disequilibrium (LD), which was confirmed by a formal LD test (table 1).

Since the $-3019 \mathrm{G}>\mathrm{A}$ and $-38 \mathrm{C}>\mathrm{T}$ SNPs are in complete $\mathrm{LD}$ and since the $T / T$ genotype of the $-38 \mathrm{C}>\mathrm{T}$ SNP was associated with low body fatness, ${ }^{18}$ then the $A / A$ genotype of the $-3019 \mathrm{G}>$ A SNP, by definition, should be associated with low body fatness. However, the functional data (fig 2) suggest the opposite. The results are therefore in disagreement in terms of LD and the functional effects of the two SNPs. However, the region that contains the $-38 \mathrm{C}>\mathrm{T}$ SNP had considerably ( $\sim 1000$-fold) higher promoter activity than the region containing the $-3019 \mathrm{G}>\mathrm{A}$ SNP (fig 2). Therefore, the net effect of the $-3019 \mathrm{~A} /-38 \mathrm{~T}$ haplotype could be determined mostly by the $-38 T$ allele at basal conditions. One way to test this hypothesis would be by using longer promoter constructs that contain both SNPs, in all possible haplogroup combinations, and evaluating the impact of each haplogroup on promoter activity. Such studies, however, could be hampered by the presence of additional SNPs in the vicinity of the -3019 or -38 SNPs.

The discovery of disease susceptibility genes is increasingly based on LD mapping with SNPs. ${ }^{27}$ Past experience with association studies shows that there may be spurious associations with functional SNPs or SNPs in LD with neighbouring loci. Here we present a case of two SNPs that are in complete LD and yet the linked genotypes have opposite functional effects. This puts emphasis on the need to functionally characterise all SNPs in LD in the promoter, as
LD may not necessarily predict the functional properties of the linked SNPs.

\section{Authors' affiliations}

F Bai, T Rankinen, C Charbonneau, C Bouchard, G Argyropoulos,

Pennington Biomedical Research Center, Baton Rouge, LA 70808, USA

D D Belsham, Department of Physiology, Division of Cellular and Molecular Biology, University of Toronto, Toronto Hospital Research Institute, Toronto, Ont., Canada M5S 1 A8

D C Rao, Division of Biostatistics and Departments of Genetics and Psychiatry, Washington University Medical School, St. Louis, MO 63110, USA

This work was supported by the National Institutes of Health, National Institute of Diabetes, and Digestive, and Kidney Diseases (grant DK62156, to GA). Denise Belsham is supported by the Canadian Institutes of Health Research and the Canada Foundation for Innovation. The HERITAGE Family Study is supported by the National Heart, Lung, and Blood Institute through grants HL45670 (to CB) and HL47317 (to DCR). Claude Bouchard is partially supported by the George A. Bray Chair in Nutrition.

Conflicts of interest: none declared.

Correspondence to: $\mathrm{G}$ Argyropoulos, $\mathrm{PhD}$, Pennington Biomedical Research Center, 6400 Perkins Road, Baton Rouge, LA 70808, USA; argyrog@pbrc.edu

Revised version received 16 January 2004

Accepted for publication 4 February 2004

\section{REFERENCES}

1 Graunke DM, Argyropoulos G. Deciphering transcriptional regulation relevant to eating behavior. Curr Genom 2003:4:623-33.

2 Ollmann MM, Wilson BD, Yang YK, Kerns JA, Chen Y, Gantz I, Barsh GS Antagonism of central melanocortin receptors in vitro and in vivo by agoutirelated protein. Science 1997;278:135-8.

3 Shutter JR, Graham M, Kinsey AC, Scully S, Luthy R, Stark KL. Hypothalamic expression of ART, a novel gene related to agouti, is up-regulated in obese and diabetic mutant mice. Genes Dev 1997; 11:593-602.

4 Schwartz MW, Woods SC, Porte D Jr, Seeley RJ, Baskin DG. Central nervous system control of food intake. Nature 2000;404:661-71.

5 Ste Marie L, Miura GI, Marsh DJ, Yagaloff K, Palmiter RD. A metabolic defect promotes obesity in mice lacking melanocortin-4 receptors. Proc Natl Acad Sci U S A 2000;97:12339-44.

6 Rossi M, Kim MS, Morgan DG, Small CJ, Edwards CM, Sunter D, Abusnana S, Goldstone AP, Russell SH, Stanley SA, Smith DM, Yagaloff K, Ghatei MA, 
Bloom SR. A C-terminal fragment of agouti-related protein increases feeding and antagonizes the effect of alpha-melanocyte stimulating hormone in vivo. Endocrinology 1998;139:4428-31

7 Graham M, Shutter JR, Sarmiento U, Sarosi I, Stark KL. Overexpression of Agrt leads to obesity in transgenic mice. Nat Genet 1997;17:273-4.

8 Small CJ, Kim MS, Stanley SA, Mitchell JR, Murphy K, Morgan DG, Ghatei MA, Bloom SR. Effects of chronic central nervous system administration of agouti- related protein in pair-fed animals. Diabetes 2001;50:248-54.

9 Havel PJ, Hahn TM, Sindelar DK, Baskin DG, Dallman MF, Weigle DS, Schwartz MW. Effects of streptozotocin-induced diabetes and insulin treatment on the hypothalamic melanocortin system and muscle uncoupling protein 3 expression in rats. Diabetes 2000;49:244-52.

10 Dhillo WS, Small CJ, Gardiner JV, Bewick GA, Whitworth EJ, Jethwa PH, Seal $\amalg$, Ghatei MA, Hinson JP, Bloom SR. Agouti-related protein has an inhibitory paracrine role in the rat adrenal gland. Biochem Biophys Res Commun 2003;301:102-7.

11 Schwartz MW, Baskin DG, Bukowski TR, Kuijper JL, Foster D, Lasser G, Prunkard DE, Porte D Jr, Woods SC, Seeley RJ, Weigle DS. Specificity of leptin action on elevated blood glucose levels and hypothalamic neuropeptide $Y$ gene expression in ob/ob mice. Diabetes 1996;45:531-5.

12 Ebihara K, Ogawa Y, Katsuura G, Numata Y, Masuzaki H, Satoh N, Tamaki M, Yoshioka T, Hayase M, Matsuoka N, Aizawa-Abe M, Yoshimasa $Y$, Nakao K. Involvement of agouti-related protein, an endogenous antagonist of hypothalamic melanocortin receptor, in leptin action. Diabetes 1999;48:2028-33.

13 Katsuki A, Sumida Y, Gabazza EC, Murashima S, Tanaka T, Furuta M, ArakiSasaki R, Hori Y, Nakatani K, Yano Y, Adachi Y. Plasma levels of agoutirelated protein are increased in obese men. J Clin Endocrinol Metab 2001;86:1921-4.

14 Shen CP, Wu KK, Shearman LP, Camacho R, Tota MR, Fong TM, Van Der Ploeg LH. Plasma agouti-related protein level: a possible correlation with fasted and fed states in humans and rats. J Neuroendocrinol 2002; 14:607-10.

15 Vink T, Hinney A, van Elburg AA, van Goozen SH, Sandkuijl LA, Sinke RJ, Herpertz-Dahlmann BM, Hebebrand J, Remschmidt $\mathrm{H}$, van Engeland $\mathrm{H}$, Adan RA. Association between an agouti-related protein gene polymorphism and anorexia nervosa. Mol Psychiatry $2001 ; 6: 325-8$.
16 Argyropoulos G, Rankinen T, Neufeld DR, Rice T, Province MA, Leon AS, Skinner JS, Wilmore JH, Rao DC, Bouchard C. A polymorphism in the human agouti-related protein is associated with late-onset obesity. J Clin Endocrinol Metab 2002;87:4198-202.

17 Mayfield DK, Brown AM, Page GP, Garvey WT, Shriver MD, Argyropoulos G. A role for the agouti related protein promoter in obesity and type 2 diabetes. Biochem Biophys Res Commun 2001;287:568-73.

18 Argyropoulos G, Rankinen T, Bai F, Rice T, Province M, Leon A, Skinner J, Wilmore J, Rao D, Bouchard B. The agouti related protein and body fatness in humans. Int J Obes 2003;27:276-80.

19 Brown AM, Mayfield DK, Volaufova J, Argyropoulos G. The gene structure and minimal promoter of the human agouti related protein. Gene $2001 ; 277: 231-8$.

20 Bai F, Argyropoulos G. Active promoter elements in the human agouti related protein gene. In: Medeiros-Neto G, Halpern A, Bouchard B, eds. 9th International Congress on Obesity. Sao Paulo, Brazil: John Libbey, 2002:753-6.

21 Bouchard C, Leon AS, Rao DC, Skinner JS, Wilmore JH, Gagnon J. The HERITAGE family study. Aims, design, and measurement protocol. Med Sci Sports Exerc 1995;27:721-9.

22 den Dunnen JT, Antonarakis SE. Nomenclature for the description of human sequence variations. Hum Genet 2001;109:121-4.

23 Mellon PL, Windle JJ, Goldsmith PC, Padula CA, Roberts JL, Weiner RI. Immortalization of hypothalamic $\mathrm{GnRH}$ neurons by genetically targeted tumorigenesis. Neuron 1990;5:1-10.

24 Belsham DD, Cai F, Cui H, Smukler SR, Salapatek AM, Shkreta L. Generation of a phenotypic array of hypothalamic neuronal cell models to study complex neuroendocrine disorders. Endocrinology 2004;145:393-400.

25 Terwilliger JD, Ott J. Handbook of human genetic linkage. Baltimore: Johns Hopkins University Press, 1994.

26 Lewontin RD. The interaction of selection and linkage. I. General considerations; heterotic models. Genetics 1964;49:49-67.

27 Nakajima T, Jorde LB, Ishigami T, Umemura S, Emi M, Lalouel JM, Inoue I. Nucleotide diversity and haplotype structure of the human angiotensinogen gene in two populations. Am J Hum Genet 2002;70:108-23. 